\author{
Magdalena Zajchowska* \\ ORCID: 0000-0003-3219-2628 \\ Uniwersytet Śląski
}

https://doi.org/10.19195/1733-5779.30.9

\title{
Postępowanie dowodowe w sprawach mobbingowych i dyskryminacyjnych
}

\section{JEL Classification: K31}

Słowa kluczowe: mobbing, dyskryminacja, ciężar dowodu, postępowanie dowodowe

Keywords: mobbing, discrimination, the burden of proof, evidence proceedings

\begin{abstract}
Abstrakt: Jedną z możliwości dochodzenia roszczeń wynikających ze stosunków zatrudnienia jest sądowe rozwiązywanie spraw. Rozstrzygnięcie sprawy przed sądem jest jednocześnie rozstrzygnięciem o roszczeniach przysługujących powodowi, które musi być poprzedzone przeprowadzeniem postępowania dowodowego. W sprawach pracowniczych pozostaje ono szczególnie skomplikowane i rozbudowane $\mathrm{z}$ uwagi na wielość faktów występujących $\mathrm{w}$ tych kategoriach spraw pracowniczych i to, że świadkowie pozostają w relacjach prawnych i faktycznych. Celem opracowania jest zatem ukazanie niektórych aspektów procesowych wskazujących na specyfikę postępowania dowodowego w sprawach mobbingowych i dyskryminacyjnych. Autorka odnosi się do ogólnych reguł procesu dotyczących ciężaru dowodu, albowiem zarówno w zakresie zarzutu podejmowania przez pracodawcę mobbingu, jak też przy zarzucie działań dyskryminujących pracownika, to na pracowniku spoczywa obowiązek dowodowy w zakresie wskazania okoliczności, które uzasadniałby roszczenie oparte na tych zarzutach. Ponadto autorka omawia charakter postępowania dowodowego w sprawach pracowniczych, z jego specyfiką, która charakteryzuje się znacznym odformalizowaniem. Autorka analizuje również poszczególne środki dowodowe, to jest dowód z dokumentu, dowód z opinii biegłego sądowego czy też inne źródła dowodowe, o których mowa w art. 308 k.p.c.
\end{abstract}

\section{Evidence proceedings in mobbing and discriminatory cases}

Abstract: One of the possibilities of pursuing claims arising from employment is the judicial resolution of cases. Judgment in court is a decision on the claims of the party, which must be preceded by the taking of evidence. The evidentiary proceedings are particularly complicated and extensive due to the multiplicity of facts occurring in these categories of employee cases as well as the fact that the witnesses remain in legal and factual relations. The aim of the study is to present some of the

* Opiekun naukowy (Scientific Tutor) — dr hab. Helena Szewczyk 
procedural aspects related to the evidentiary proceedings in mobbing and discriminatory cases. The author refers to the general rules of the process regarding the rules of proof, because the employee has the burden of proof in the scope of indicating circumstances that would justify a claim based on mobbing and discrimination. The author discusses the nature of evidence proceedings in employee cases, with its specificity, which is characterized by considerable deformalization. The author also analyzes the types of evidence, such as documentary evidence, evidence from the expert's opinion, or other sources of evidence referred to in Article 308 of the Code of Civil Procedure.

\section{Uwagi wstępne}

Rozwiązywanie konfliktów w sferze zatrudnienia może następować na drodze sądowej, jak również na etapie poprzedzającym sądowe dochodzenie roszczeń. W doktrynie oraz praktyce rozróżnia się bowiem sądowy oraz pozasądowy model ochrony prawnej $\mathrm{w}$ indywidualnych sporach pracy ${ }^{1}$. Za model pozasądowy należy uznać każdy inny sposób rozstrzygnięcia sprawy niż w drodze postępowania przed sądem powszechnym. Przykładem takiego rozwiązywania sporów są między innymi negocjacje i mediacje $\mathrm{w}$ miejscu pracy. W ramach pozasądowego rozwiązywania sporów praktyka zna również przykłady powołania wewnątrzzakładowej komisji mającej na celu przeciwdziałanie patologiom w miejscu pracy. Należy podkreślić, że do wskazanych sposobów rozwiązywania konfliktów nie mają zastosowania przepisy kodeksu postępowania cywilnego (dalej k.p.c.), albowiem wskazane metody rozwiązywania konfliktów w sferze zatrudnienia mają charakter nieformalny ${ }^{2}$.

Spór może zostać również rozwiązany metodami bardziej sformalizowanymi, to znaczy poprzez zawarcie ugody przed komisją pojednawczą, o której mowa w art. 244 i następnych kodeksu pracy ${ }^{3}$ (dalej: k.p.). Zgodnie z art. 255 $\S 1$ k.p. ${ }^{4} \mathrm{~W}$ razie niewykonania ugody przez pracodawcę podlega ona wykonaniu w trybie przepisów kodeksu postępowania cywilnego, po nadaniu jej przez sąd pracy klauzuli wykonalności. Kolejno strony konfliktu mogą również poddać rozwiązanie sprawy organowi ochrony prawnej, czyli mogą uczynić zapis na sąd polubowny. W sprawach pracowniczych możliwe jest również zawarcie ugody przed sądem lub mediatorem ${ }^{5}$.

Niemniej jednak jedną z możliwości dochodzenia roszczeń wynikających ze stosunków zatrudnienia jest rozwiązywanie sporów przed sądem pracy w postaci procesu sądowego. Rozstrzygnięcie sprawy przed sądem powoduje powstanie arbitralnego rozstrzygnięcia, któremu będą musiały podporządkować się strony

1 K.W. Baran, Procesowe prawo pracy, Warszawa 2013, s. 42.

2 Ustawa z dnia 17 listopada 1964 roku Kodeks postępowania cywilnego (tekst jedn. Dz.U. z 2018 r. poz. 1360).

3 Ustawa z dnia 26 czerwca 1974 roku Kodeks pracy (tekst jedn. Dz.U. z 2018 r. poz. 917).

4 Art. 255 § 1 k.p.

${ }^{5}$ H. Szewczyk, Równość ptci w zatrudnieniu, Warszawa 2017, s. 558 n.; G. Jędrejek, Dochodzenie roszczeń związanych z mobbingiem, dyskryminacją i molestowaniem, Warszawa 2017, s. $59 \mathrm{n}$. 
procesu. Wniesienie pozwu przez pracownika nie musi być poprzedzone skorzystaniem z wewnątrzzakładowych procedur rozwiązania konfliktu na tle mobbingu czy dyskryminacjí.

Sąd może zakończyć proces w sposób pozamerytoryczny, wydając postanowienie o odrzuceniu pozwu, o czym mowa w art. 199 § 1 k.p.c. ${ }^{7}$, jak również na podstawie art. $355 \S 1$ k.p.c. sąd może umorzyć postępowanie, jeżeli wydanie wyroku stało się zbędne lub niedopuszczalne. Kolejnymi rozstrzygnięciami sądu może być uwzględnienie powództwa w całości lub w części lub oddalenie powództwa. Wydanie wyroku uwzględniającego lub oddalającego powództwo stanowi zgodnie $\mathrm{Z}$ art. $777 \S 1$ pkt 1 k.p.c. tytuł egzekucyjny.

Zgodnie z zasadą dyspozycyjności sąd nie wszczyna postępowania z urzędu. Inicjowane jest ono wniesieniem pozwu przez stronę. Rozstrzygnięcie sprawy przed sądem stanowi jednocześnie rozstrzygnięcie o roszczeniach przysługujących powodowi. Musi być poprzedzone przeprowadzeniem postępowania dowodowego, które w sprawach pracowniczych pozostaje szczególnie skomplikowane i rozbudowane, ze względu na wielość faktów występujących w tych kategoriach spraw i to, że świadkowie pozostają w relacjach prawnych i faktycznych ze stronami sporu. Świadkami są bowiem najczęściej pracownicy zatrudnieni u pracodawcy będącego jednocześnie stroną postępowania. Jeżeli zatem pozwanym jest pracodawca, to z pewnością istnieje niebezpieczeństwo stronniczości zeznań. Łączący strony stosunek prawny nie jest stosunkiem chwilowym, lecz trwałym stosunkiem prawnym o zasadniczym znaczeniu dla świadka. Pozostawanie zatem w stosunku zależności może wpływać na treść zeznań świadka. Nawet podświadomie świadek będzie czuł, że w przyszłości może ponieść konsekwencje wynikające ze złożonych zeznań. Podobny wpływ na treść zaznań wywierają relacje faktyczne łączące świadków i strony procesu. Bez wątpienia bowiem w pracy tworzą się relacje koleżeńskie lub rodzinne. Nierzadko również na świadka powołany zostaje były pracownik, a na treść jego zeznań ma wpływ atmosfera, w której rozstał się z pracodawcą. Nie ulega zatem wątpliwości, że przy ocenie takich zeznań sąd musi zachować szczególną ostrożność ${ }^{8}$.

Problematyka procesów sądowych w sprawach mobbingowych i dyskryminacyjnych z punktu widzenia strony powodowej sprowadza się zatem do trudności związanej z udowodnieniem, czy mobbing i dyskryminacja w istocie miały miejsce.

6 G. Jędrejek, op. cit., s. 147.

7 Zgodnie z art. 199 § 1 k.p.c sąd odrzuci pozew, jeżeli: droga sądowa jest niedopuszczalna (pkt 1); o to samo roszczenie pomiędzy tymi samymi stronami sprawa jest $\mathrm{w}$ toku albo została już prawomocnie osądzona (pkt 2); jedna ze stron nie ma zdolności sądowej albo powód nie ma zdolności procesowej, a nie działa za niego przedstawiciel ustawowy albo jeżeli w składzie organów jednostki organizacyjnej będącej powodem zachodzą braki uniemożliwiające jej działanie (pkt 3).

${ }^{8}$ G. Jędrejek, op. cit., s. 255, 278-280. 
Celem niniejszego opracowania jest zatem ukazanie niektórych aspektów procesowych wskazujących specyfikę postępowania dowodowego w sprawach mobbingowych i dyskryminacyjnych zawisłych przed sądem pracy.

\section{Charakter postępowania dowodowego w sprawach pracowniczych}

Nie bez wpływu na postępowanie dowodowe w sprawach mobbingowych i dyskryminacyjnych pozostaje charakter postępowania dowodowego. Sprawy z zakresu mobbingu oraz dyskryminacji należą do spraw pracowniczych, w związku z czym rozpoznawane są w trybie postępowania odrębnego, który został uregulowany przez ustawodawcę w art. 459-476 k.p.c. (przepisy ogólne) oraz w art. 477$477^{7}$ (przepisy w sprawach z zakresu prawa pracy). Oznacza to, iż w sprawach pracowniczych przede wszystkim zastosowanie mają przepisy regulujące odrębności postępowania z zakresu prawa pracy, a następnie ogólne przepisy k.p.c. ${ }^{9}$

Postępowanie dowodowe w sprawach pracowniczych charakteryzuje się znacznym odformalizowaniem ${ }^{10}$. Wskazując na poszczególne przykłady, można się odwołać do postulatu z art. 471 k.p.c., zgodnie z którym termin rozprawy powinien być wyznaczony tak, aby od daty zakończenia czynności wyjaśniających, a jeżeli nie podjęto tych czynności - od daty wniesienia pozwu lub odwołania do rozprawy nie upłynęło więcej niż dwa tygodnie, chyba że zachodzą niedające się usunąć przeszkody ${ }^{11}$. Uproszczony został również sposób wezwania stron, świadków, biegłych i innych osób. Ustawodawca umożliwia odejście od sposobów zawartych w przepisach ogólnych kodeksu postępowania cywilnego (art. 472 k.p.c.) ${ }^{12}$. Nie bez znaczenia pozostaje również art. 473 k.p.c., zgodnie z którym ustawodawca wskazal, że w postępowaniu w sprawach między innymi z zakresu prawa pracy nie stosuje się przepisów ograniczających dopuszczalność dowodu ze świadków lub zakazów dowodowych dotyczących przesłuchania stron ${ }^{13}$.

Kolejny przykład odformalizowania postępowania w sprawach pracowniczych stanowi przepis art. 466 k.p.c., zgodnie z którym pracownik lub ubezpieczony działający bez adwokata lub radcy prawnego może zgłosić w sądzie właściwym ustnie do protokołu powództwo oraz treść środków odwoławczych i innych pism procesowych ${ }^{14}$. Przytoczony przepis ma ułatwić dochodzenie roszczeń pracowni-

9 H. Szewczyk, op. cit., s. 568-569; G. Jędrejek, Postępowanie dowodowe w sprawie mobbingowej, „Monitor Prawa Pracy” 2008, nr 12, s. 626.

10 G. Jędrejek, Dochodzenie roszczeń zwiąanych z mobbingiem..., s. 249 n.

11 Art. 471 k.p.c.

12 G. Jędrejek, Postępowanie dowodowe..., s. 626.

13 Art. 473 k.p.c.

14 Art. 466 k.p.c.

Studenckie Prace Prawnicze, Administratywistyczne

(C) for this edition by CNS 
kom, którzy działając bez profesjonalnego pełnomocnika, mogliby mieć trudności ze sformułowaniem swych żądań ${ }^{15}$.

Następnie należy wskazać, że w przepisach ogólnych k.p.c., to jest w art. 194 k.p.c. $\S 1$, wskazano, że jeżeli okaże się, że powództwo nie zostało wniesione przeciwko osobie, która powinna być w sprawie stroną pozwaną, sąd na wniosek powoda lub pozwanego wezwie tę osobę do wzięcia udziału w sprawie ${ }^{16}$. Natomiast $\mathrm{w}$ sprawach $\mathrm{z}$ zakresu prawa pracy, $\mathrm{w}$ których pracownik stanowi stronę powodową, art. 477 k.p.c. upoważnia do wezwania takich osób również przez sąd $\mathrm{z}$ urzędu ${ }^{17}$. O wezwaniu do wzięcia udziału w sprawie w charakterze pozwanego (art. $194 \S 1$ k.p.c.) sąd orzeka zawsze postanowieniem wydanym na rozprawie, także wtedy gdy wezwania do udziału w sprawie może dokonać z urzędu (art. 477 k.p.c. $)^{18}$.

Dodatkowo, odnosząc się również do przepisów ogólnych k.p.c., należy zauważyć, że na strony postępowania nie został nałożony obowiązek wskazania podstawy prawnej żądania. Dopiero bowiem podczas wyrokowania sąd dokona z urzędu subsumpcji stanu faktycznego. W art. 127 k.p.c. ustawodawca podkreślił, że w pismach procesowych strony mogą wskazywać podstawy prawne swoich żądań lub wniosków ${ }^{19}$. Co więcej, odnosząc się do przepisu art. $210 \S 1$ zdanie drugie k.p.c., ustawodawca podniósł, że strony mogą po wywołaniu sprawy wskazywać podstawy prawne swych żądań i wniosków ${ }^{20}$. Z tego wynika zatem, że nie ma obowiązku wskazania podstawy prawnej. Niemniej jednak w wypadku gdy strona reprezentowana jest przez profesjonalnego pełnomocnika, wskazywanie podstawy prawnej swych żądań należy uznać za celowe ${ }^{21}$. Przy czym w sprawach mobbingowych lub dyskryminacyjnych wskazanie podstawy prawnej można uznać za pożądane z uwagi na występujący niejednokrotnie zbieg roszczeń. Często bowiem poszczególne zachowania w miejscu pracy wyczerpują znamiona kilku zjawisk patologicznych $^{22}$.

Odnosząc się z kolei do charakteru postępowania dowodowego, należy zwrócić szczególną uwagę na zasadę kontradyktoryjności procesu cywilnego. Co prawda w przepisach art. 3, art. 232 k.p.c. ograniczona została aktywność sądu w toku postępowania dowodowego, niemniej jednak, jak wskazuje się w orzecznictwie Sądu Najwyższego, wymienione przepisy nie zwalniają sądu z obowiązku działania z urzędu z uwagi na to, że sąd ma prawo, a nie obowiązek działania z urzędu,

15 A. Zieliński, Kodeks postępowania cywilnego. Komentarz, Warszawa 2017, art. 466, nb 1, S. 888 .

16 Art. 194 k.p.c.

17 Wyrok SN z dnia 24 września 2009 roku, sygn. akt II PK 78/09, LEX nr 558307.

18 Uchwała SN z dnia 7 stycznia 2010 roku, sygn. akt II PZP 13/09, LEX nr 537073.

19 A. Zieliński, op. cit., art. 127, nb 2, s. 273 n.

20 Art. $210 \S 1$ k.p.c.

21 A. Zieliński, op. cit., art. 127, nb 3, s. 445 n.

22 G. Jędrejek, Dochodzenie roszczeń związanych z mobbingiem..., s. 252. 
a co więcej sąd powinien jednak takie działanie podjąć, gdy obowiązek ten wynika z wyraźnego unormowania kodeksu bądź w sprawie ujawniono środki dowodowe istotne dla rozstrzygnięcia sprawy. Przy czym w orzecznictwie wskazuje się także, że przy dopuszczeniu przez sąd dowodów z urzędu na podstawie art. 232 k.p.c. znaczenie odgrywa rodzaj sprawy ${ }^{23}$. Na przykład w sprawach mobbingowych sąd nie może z urzędu dopuścić dowodu co do tego, czy mobbing był stosowany, ponieważ przeważa pogląd, że zasada kontradyktoryjności wyklucza prawo sądu do zarządzenia odpowiedniego dochodzenia w celu ustalenia koniecznych dowodów. Niemniej jednak sąd może dopuścić dowód z urzędu z opinii biegłego co do wywołania rozstroju zdrowia wskutek mobbingu, jeżeli strona nie stwierdza, że doznała rozstroju zdrowia. $Z$ sytuacją taką mamy do czynienia, gdy pracownik będzie żądał zadośćuczynienia bez wskazania, że doznał rozstroju zdrowia. Wskazuje się bowiem, że informacja o istnieniu potrzebnego dowodu może pochodzić tylko z akt sprawy lub z oświadczeń składanych przez strony ${ }^{24}$.

Jednak zarówno w doktrynie, jak i orzecznictwie wskazuje się, że mimo iż sprawy pracownicze należą do uprzywilejowanych, to obowiązki sądu w tych sprawach nie mogą być interpretowane rozszerzająco ${ }^{25}$. W orzecznictwie podnosi się także, że w postępowaniu z zakresu prawa pracy i ubezpieczeń społecznych nie jest znana zasada, która nakazywałaby sądom tłumaczyć wszelkie niejasności, zarówno prawne, jak i faktyczne, na korzyść pracownika ${ }^{26}$.

\section{Ciężar dowodu w sprawach mobbingowych i dyskrymiacyjnych}

Omawiając ciężar dowodu w sprawach mobbingowych i dyskryminacyjnych, należy odnieść się do ogólnych reguł procesu, to jest art. 6 kodeksu cywilnego, zgodnie z którym ciężar udowodnienia faktu spoczywa na osobie, która z faktu tego wywodzi skutki prawne ${ }^{27}$. Co do zasady zatem ciężar dowodu spoczywa na powodzie, który musi udowodnić okoliczności wskazane w pozwie. Z kolei na pozwanym spoczywa obowiązek udowodnienia okoliczności wskazanych w podniesionych zarzutach ${ }^{28}$

Niemniej jednak nieco inną postać przybiera ciężar dowodu w sprawach dyskryminacyjnych. Fakty przedstawione przez pracownika mają uprawdopodobnić

23 Postanowienie SN z dnia 7 grudnia 2000 roku, sygn. akt II CKN 1322/00, LEX nr 51967; wyrok SN z dnia 5 lutego 1997 roku, sygn. akt I CKU 81/96, LEX nr 50574.

${ }^{24}$ M. Jaślikowski, Prawo sądu do przeprowadzenia z urzędu dowodów niewskazanych przez strony w świetle zasad i funkcji postępowania cywilnego, „Przegląd Sądowy” 2005, nr 11-12, s. 92.

25 Ibidem, s. 90.

26 Wyrok SN z dnia 4 lipca 2000 roku, sygn. akt II UKN 627/99, OSNP 2002/2/50; wyrok SN z dnia 10 listopada 1999 roku, sygn. akt I PKN 361/99, LEX 40658.

27 Ustawa z dnia 23 kwietnia 1964 roku Kodeks cywilny (tekst jedn. Dz.U. z 2018 r. poz. 1025).

28 Wyrok SA w Krakowie z dnia 29 sierpnia 2018 roku, sygn. akt I ACa 1635/17, LEX nr 2554202. 
zaistnienie dyskryminacji ${ }^{29}$. Należy zatem przyjąć, że w postępowaniach tego rodzaju zastosowanie może mieć art. 243 k.p.c., zgodnie z którym zachowanie szczegółowych przepisów o postępowaniu dowodowym nie jest konieczne, ilekroć ustawa przewiduje uprawdopodobnienie zamiast dowodu. Jest to korzystne dla pracownika, gdyż uprawdopodobnienie nie jest poddane ścisłym regułom dowodzenia, natomiast musi zachować walor wiarygodności w świetle reguł logiki i doświadczenia życiowego ${ }^{30}$. Pracownik zwolniony jest zatem z konieczności udowodnienia jego dyskryminacji. Uprawdopodobnienie polega na obowiązku przedstawienia przez pracownika faktów, z których można domniemywać istnienie dyskryminacji, z kolei żeby uwolnić się od odpowiedzialności pracodawca musi udowodnić, że nie dyskryminuje pracownika. Inaczej mówiąc, musi wykazać, że różnicując sytuację pracownika, kierował się obiektywnymi powodami, a nie kryteriami zakazanymi przez art. $18^{3 \mathrm{a}} \S 1$ k.p..$^{31}$

Podkreślenia jednak wymaga, że przerzucenie ciężaru dowodu na pozwanego ma zapewnić równowagę między potrzebą ochrony podstawowych praw jednostki a zapobieganiem obciążenia powoda trudnymi do wypełnienia obowiązkami dowodowymi. Ponadto powód często nie ma dostępu do dowodów świadczących o dyskryminacji, znajdują się one bowiem w posiadaniu pozwanego ${ }^{32}$.

Z kolei w zakresie zarzutu podejmowania przez pracodawcę mobbingu, to na pracowniku spoczywa obowiązek dowodowy w zakresie wskazania okoliczności, które uzasadniałyby roszczenie oparte na tych zarzutach. Jak wskazuje się w orzecznictwie, dopiero wykazanie tych okoliczności pozwala przerzucić na pracodawcę obowiązek przeprowadzenia dowodu przeciwnego. Wskazuje się bowiem, że nie sposób wymagać od pracodawcy, aby spotykał się z subiektywnym poczuciem jakiejś, choćby całkowicie wyimaginowanej, dyskryminacji i próbował każdemu pracownikowi, w tym także trapionym zawyżoną samooceną własnej wartości na rynku pracy, wykazywać z góry, że nie dopuścił się wobec nich jakiegokolwiek aktu dyskryminacyjnego ${ }^{33}$. Powyższe znajduje wyraz w wyroku Sądu Apelacyjnego w Gdańsku, w którym świadkowie wskazali, iż nie byli uczestnikami niewłaściwych zachowań przełożonych wobec powódki, to jest upokarzania powódki w codziennych sytuacjach pracowniczych, do których należą ukaranie powódki karą nagany z powodu naruszenia obowiązków pracowniczych, kierowanie powódki na mniejszą liczbę szkoleń niż w latach poprzednich, odpowiadanie na e-maile w krótkim terminie czy niezaproszenie jej na spotkanie z ministrem. W całym postępowaniu powódka składała wiele wniosków oraz opisywała liczne

29 Wyrok SN z dnia 18 kwietnia 2012 roku, sygn. akt II PK 196/11, LEX nr 1297762.

30 E. Naumann, Dyskryminacja w prawie pracy, „Monitor Prawa Pracy” 2007, nr 6, s. 289.

31 E. Maniewska, Kodeks Pracy. Komentarz, LEX/el., 2018; wyrok SN z dnia 20 lipca 2017 roku, sygn. akt I PK 216/16, Lex nr 2389574.

32 E. Naumann, op. cit., s. 289.

33 Postanowienie SN z dnia 24 maja 2005 roku, sygn. akt II PK 33/05, LEX nr 184961. 
sytuacje, które w jej ocenie mogły świadczyć o mobbingu ze strony pozwanego pracodawcy, jednakże żadne z zachowań pracodawcy nie świadczy o stosowaniu mobbingu wobec powódki ${ }^{34}$.

Należy również zauważyć, że w sprawach mobbingowych na pracowniku spoczywa obowiązek udowodnienia nie tylko stosowania mobbingu, lecz także, że wynikiem nękania był rozstrój zdrowia ${ }^{35}$. Ustawowe przesłanki mobbingu muszą być spełnione łącznie, w związku z czym pracownik winien udowodnić, że został poddany mobbingowi oraz że rozstrój zdrowia, w wypadku żądania zadośćuczynienia, został wywołany mobbingiem ${ }^{36}$.

\section{3. Środki dowodowe w sprawach mobbingowych i dyskryminacyjnych}

W postępowaniu cywilnym środki dowodowe mają niewątpliwie olbrzymie znacznie. Wskazuje się, że środkiem dowodowym jest informacja, którą uczestnicy procesu uzyskują ze źródła dowodowego w związku z ustaleniem faktów w procesie cywilnym ${ }^{37}$. Z kolei faktem dowodowym będzie wyróżniony opisowo wraz z wypowiedzią o jego wartości, stanowiącą zwrot oceniający. Natomiast źródłem dowodowym jest osoba lub rzecz, która dostarcza lub może dostarczyć informacji związanych z ustaleniem podstaw decyzji procesowych. Materiałem dowodowym $\mathrm{z}$ kolei będzie materialna forma przekazywania informacji ${ }^{38}$.

Wskazując $\mathrm{z}$ kolei na postępowania sądowe $\mathrm{w}$ sprawach pracowniczych, zasadnicze znaczenie będą miały: dowód z zeznań świadków, dowód z opinii biegłego sądowego, przesłuchanie stron lub też inne źródła dowodowe zawierające zapis obrazu, dźwięku albo obrazu i dźwięku, o których mowa w art. 308 k.p.c. ${ }^{39}$

Szczególne rolę w sprawach pracowniczych będzie odgrywać dowód z dokumentu. Mimo braku definicji kodeksowej dokumentu w nauce prawa procesowego cywilnego i praktyce przyjmuje się, że dokumentem jest utrwalone wyłącznie w formie pisemnej uzewnętrznienie wszelkiego rodzaju spostrzeżeń, myśli, oświadczeń ludzkich, nadające się do wielokrotnego wykorzystania ${ }^{40}$. Na gruncie prawa procesowego rozróżniamy dwa typy dokumentu: urzędowe i prywatne. Zgodnie z art. $244 \S 1$ k.p.c. ${ }^{41}$ dokumenty urzędowe sporządzone w przepisanej

34 Wyrok SA w Gdańsku z dnia 16 czerwca 2016 roku, sygn. akt III APa 13/16, LEX nr 2356487.

35 Wyrok SN z dnia 5 października 2007 roku, sygn. akt II PK 31/07, LEX nr 465076.

36 Wyrok SN z dnia 5 grudnia 2006 roku, sygn. akt II PK 112/06, LEX nr 290991.

37 Ł. Błaszczak, Dowody i postępowanie dowodowe w sprawach cywilnych, red. Ł. Błaszczak, K. Markiewicz, Warszawa 2005, s. 17, 32-33.

38 J. Wróblewski, Sądowe stosowanie prawa, Warszawa 1988, s. 184.

39 H. Szewczyk, op. cit., s. 57.

40 T. Demendecki, Kodeks postępowania cywilnego, t. 1. Komentarz do art. 1-729, red. A. Jakubecki, Warszawa 2017.

41 Art. $244 \S 1$ k.p.c. 
formie przez powołane do tego organy władzy publicznej i inne organy państwowe w zakresie ich działania stanowią dowód na to, co zostało w nich urzędowo zaświadczone. $Z$ kolei zgodnie z art. 245 k.p.c. ${ }^{42}$ dokument prywatny sporządzony $\mathrm{w}$ formie pisemnej albo elektronicznej stanowi dowód tego, że osoba, która go podpisała, złożyła oświadczenie zawarte w dokumencie. Wydawać by się mogło, że w sprawach pracowniczych zasadnicze znaczenie będzie miał dowód z dokumentu prywatnego, niemniej jednak uwagi wymaga, że w sprawach mobbingowych i dyskryminacyjnych mobber czy osoba dyskryminująca nie pozostawia po sobie śladu w postaci dokumentów. Pracownik może uzyskiwać wiadomości e-mail, które mogą być dowodem w postępowaniu sądowym. Co więcej, może uzyskać dokument świadczący o dyskryminacji lub mobbingu, zwracając się do pracodawcy o wydanie polecenia na piśmie. Dotyczy to sytuacji, w której mobberem lub osobą dyskryminującą jest pracodawca ${ }^{43}$.

Kolejnym środkiem dowodowym, jaki można powołać w trakcie procesu, jest dowód z zeznań świadków. Przy czym zgodnie z art. 258 k.p.c. ${ }^{44}$ strona powołująca się na dowód ze świadków zobowiązana jest dokładnie oznaczyć fakty, które mają być stwierdzone zeznaniami poszczególnych świadków i wskazać świadków, tak by wezwanie ich do sądu było możliwe. Do faktów, które mają być stwierdzone zeznaniami świadków, należy zaliczyć zachowania mobbingowe lub też zachowania skutkujące dyskryminacją. Niemniej jednak z uwagi na specyfikę spraw pracowniczych, między innymi związanie z pracodawcą, zeznania współpracowników czy byłych pracowników mogą okazać się niezgodne z prawdą. Bez wątpienia może również wystąpić stronniczość zeznań. Wiadomo bowiem, że stosunek pracowniczy odgrywa znaczącą rolę w życiu pracownika ${ }^{45}$. Dlatego też zasadne wydaje się konfrontowanie zeznań świadków z innymi dowodami dopuszczonymi w sprawie. W doktrynie szeroko wskazuje się, że w sprawach mobbingowych i dyskryminacyjnych sąd winien podchodzić z dużą rozwagą do dowodu z zeznań świadków, a ocena zeznań świadków powinna opierać się na zestawieniu treści zeznań z pozostałymi dowodami naświetlającymi okoliczności sprawy w sposób odmienny oraz na dokonaniu prawidłowego wyboru, po rozważeniu wynikłych sprzeczności w świetle zasad logiki i doświadczenia życiowego ${ }^{46}$.

Ponadto zgodnie z art. 261 § 2 k.p.c. ${ }^{47}$ świadek może odmówić odpowiedzi na zadane mu pytanie, jeżeli zeznanie mogłoby narazić jego lub jego bliskich, wymienionych w paragrafie poprzedzającym, na odpowiedzialność karną, hańbę

42 Art. 245.

43 G. Jędrejek, Postępowanie dowodowe..., s. 628.

44 Art. 258 k.p.c.

45 G. Jędrejek, Dochodzenie roszczeń związanych z mobbingiem..., s. $278 \mathrm{n}$.

${ }^{46}$ K. Flaga-Gieruszyńska, Postępowanie dowodowe w sprawach z zakresu prawa pracy, [w:] System Prawa Pracy, t. 6. Procesowe prawo pracy, red. K.W. Baran, Warszawa 2016, s. 631; wyrok SA w Poznaniu z dnia 22 września 2005 roku, sygn. akt III APa 60/05, LEX nr 215691.

47 Art. $261 \S 2$ k.p.c. 
lub dotkliwą i bezpośrednią szkodę majątkową albo jeżeli zeznanie miałoby być połączone z pogwałceniem istotnej tajemnicy zawodowej. Wydaje się, że w sprawach sądowych z zakresu mobbingu czy dyskryminacji pracownicy często będą korzystać z odmowy odpowiedzi na zadane pytanie ${ }^{48}$.

Kolejnym środkiem dowodowym może okazać się dowód z opinii biegłego sądowego. Stanowi on przykład dowodu, który może dopuścić sąd, a nie został on wskazany przez stronę ${ }^{49}$. Wskazuje się jednak, że dopuszczenie dowodu z opinii biegłego powinno mieć charakter wyjątkowy, co oznacza, że uzupełnienie materiału dowodowego tym dowodem powinno nastąpić w sytuacji, gdy zebrany w sprawie materiał nie wystarcza do jej rozstrzygnięcia. Niemniej jednak ocena, czy materiał dowodowy sprawy nie jest kompletny i czy zachodzi potrzeba uzupełnienia materiału dowodowego, leży w gestii sądu ${ }^{50}$. Dodatkowo dopuszczenie takiego dowodu w sprawie nie może prowadzić do naruszenia bezstronności sądu oraz nie może być działaniem dokonanym wyłącznie w interesie jednej ze stron ${ }^{51}$.

Możliwe jest także powołanie dowodu z opinii dwóch biegłych, a w razie ich sprzeczności ich konfrontacja lub powołanie dowodu z kolejnych opinii ${ }^{52}$. W sprawach mobbingowych i dyskryminacyjnych powoływani zostają biegli sądowi z zakresu psychologii i psychiatrii. W jednej z takich spraw biegli sądowi psycholog i psychiatra zdiagnozowali powódkę jako osobę wrażliwą o niskiej tolerancji na stres, która jednak reaguje na sytuacje stresogenne jak przeciętny człowiek. Nie występują u niej zaburzenia psychosomatyczne ani osobowościowe. Na skutek zachowań pozwanego powódka doznała rozstroju zdrowia w postaci zaburzeń depresyjno-lękowych, które były skutkiem adaptacyjnej reakcji na stres. Ujawniły się u niej problemy psychologiczne w postaci bólów żołądka, bezsenności, lękliwości, rozdrażnień i skłonności do płaczu. Zaburzenia te miały podłoże nerwicowe, ale były łagodne, jednak na skutek zachowań pozwanego powódka czuła się ,gorszym pracownikiem". Powódka pozostawała w zatrudnieniu w kancelarii komorniczej, a pozwanym pracodawcą (mobberem) był komornik. Odmowa spotkań towarzyskich rozpoczęła działania mobbingowe w stosunku do zatrudnionej. Działania te były uporczywe, wyczerpywały znamiona mobbingu, w związku z czym sąd zasądził na rzecz powódki zadośćuczynienie. Biegli sądowi uznali, iż zaburzenia nerwicowe, które wystąpiły u powódki, miały łagodny charakter, co wpłynęło na wysokość zadośćuczynienia w kwocie 3 tysięcy zł. Dodatkowo biegli uznali, iż powódka reaguje na stres jak przeciętny człowiek ${ }^{53}$. Uznanie wówczas, że powódka w sytuacji mobbingowej zachowuje się jak normalny człowiek, potwierdza

48 G. Jędrejek, Postępowanie dowodowe..., s. 628.

49 M. Manowska, Postepowanie odrębne w procesie cywilnym, Warszawa 2003, s. 80.

50 Wyrok SN z dnia 12 grudnia 2000 roku, sygn. akt V CKN 175/00, LEX nr 47717; wyrok SN z dnia 10 grudnia 1997 roku, sygn. akt II UKN 394/97, LEX nr 33911.

51 H. Szewczyk, op. cit., s. 569 n.

52 Wyrok SN z dnia 30 listopada 1999 roku, sygn. akt II UKN 220/99, LEX nr 46321.

53 Wyrok SN z dnia 29 marca 2007 roku, sygn. akt II PK 228/06, LEX nr 389285. 
aktualną linię orzeczniczą sądu najwyższego, zgodnie z którą konieczne staje się stworzenie obiektywnego wzorca ofiary rozsądnej, co z zakresu mobbingu pozwoli wyeliminować przypadki wynikające z nadmiernej wrażliwości pracownika lub braku takiej wrażliwości. Badanie i ocena subiektywnych odczuć osoby, która uważa, że znęca się nad nią jej przełożony, nie może stanowić podstawy do ustalania odpowiedzialności za mobbing. Ocena, czy nastąpiło nękanie i zastraszanie pracownika oraz czy działania te miały na celu i mogły lub doprowadziły do zaniżonej oceny jego przydatności zawodowej, do jego poniżenia, ośmieszenia, izolacji bądź wyeliminowania z zespołu współpracowników, musi opierać się na obiektywnych kryteriach ${ }^{54}$.

Uwagi wymaga, że co prawda sąd nie jest związany opiniami biegłych sądowych, jednak w sprawach z zakresu wiedzy medycznej nieuwzględnienie takiej opinii uzasadnia zarzut naruszenia art. $233 \S 1$ k.p.c. przez przekroczenie granic swobodnej oceny środków dowodowych. Przy czym dowód z opinii biegłego sądowego nie może być jedyną podstawą orzeczenia sądu. Opinia biegłego powinna mieć charakter kompletny, co oznacza między innymi, że powinna się opierać na całościowym materiale dowodowym. Niedopuszczalne jest przy tym takie ukierunkowanie działania biegłego, które doprowadziłoby do wykorzystania przy opracowaniu opinii jednej grupy dowodów, dotyczących tej samej kwestii ${ }^{55}$.

W orzecznictwie szeroko wskazuje się również, że niedopuszczalny jest dowód $\mathrm{z}$ opinii biegłego sądowego $\mathrm{w}$ celu ustalenia, czy pracownik został poddany mobbingowi. W związku z tym sąd nie może dopuszczać dowodu w postaci opinii biegłego sądowego na okoliczność ustalenia, czy zachowanie mobbera spełnia przesłanki ,uporczywości”, czy „długotrwałości”, o czym mowa w definicji mobbingu — art. $94^{3} \S 2$ k.p. Dowód taki powinien być przeprowadzony na okoliczność, czy powód doznał rozstroju zdrowia, w wypadku gdy domaga się zadośćuczynienia na podstawie art. $94^{3} \S 3$ k.p. Niemniej jednak powołanie biegłego powinno nastąpić dopiero w sytuacji stwierdzenia mobbingu przez sąd ${ }^{56}$. W orzecznictwie wskazuje się zatem, że skoro brakuje podstaw do uznania, że pracownik był obiektem zachowań o charakterze mobbingu ze strony pracodawcy, to słuszne jest oddalenie wniosku o dopuszczenie dowodu z opinii biegłego lekarza dla ustalenia, czy istnieje związek przyczynowy między stanem zdrowia pracownika a sugerowanym przez niego negatywnym zachowaniem pracodawcy. Przykładem jest wyrok Sądu Apelacyjnego w Katowicach, który uznał, iż sąd pierwszej instancji słusznie oddalił wniosek o dopuszczenie dowodu z opinii biegłego lekarza do ustalenia, czy istnieje związek przyczynowy między stanem zdrowia powódki a sugerowanym przez nią negatywnym zachowaniem pracodawcy. Powódka wskazała wiele faktów, które jej zdaniem są przykładem mobbingu stosowanego wobec niej przez dyrektora szkoły.

54 Wyrok Sądu Najwyższego z dnia 29 stycznia 2019 roku, sygn. akt III PK 6/18, LEX nr 2619173.

55 Wyrok SN z dnia 7 grudnia 1994 roku, sygn. akt II URN 43/94, LEX nr 121.

56 Wyrok SN z dnia 7 października 1998 roku, sygn. akt II UKN 246/98, LEX nr 37701. 
Powoływała się na następujące sytuacje: zabranie jej lekcji plastyki, podczas gdy była jedynym nauczycielem plastyki w szkole, zabranie dodatku motywacyjnego za odmowę wyjazdu na zieloną szkołę, zabranie wychowawstwa w klasie pierwszej, dodatkowe lekcje wychowania fizycznego, niezauważanie osiągnięć powódki poprzez odnotowywanie jej sukcesów bezosobowo „zdobyła”, „osiągała”, brak obrony przez dyrektora szkoły w czasie komisji kwalifikacyjnej powołanej do oceny powódki w celu uzyskania awansu. Podnosiła, że te sytuacje były przejawem stosowania wobec niej mobbingu. W ocenie sądu w przytoczonej sprawie nie było podstaw uznania, że powódka była obiektem zachowań o charakterze mobbingu ze strony pracodawcy, w związku z czym doznała rozstroju zdrowia. W związku z powyższym oddalenie wniosku o dopuszczenie dowodu z opinii biegłego lekarza okazało się zasadne 57 .

Trzeba również zauważyć, że w art. 308 k.p.c. wskazano też inne środki dowodowe zawierające zapis obrazu, dźwięku albo obrazu i dźwięku. W orzecznictwie wskazuje się, że cytowany przepis wyróżnia kategorię dowodów z urządzeń utrwalających albo przenoszących obrazy lub dźwięki, katalog zaś środków dowodowych o tym charakterze ma postać otwartą. Ustawodawca wylicza przykładowe dowody, które powszechnie dzieli się na dwie grupy — dowody wizualne, czyli zawierające informacje postrzegane za pomocą wzroku (dowód z filmu, telewizji, fotokopii, fotografii, planów i rysunków), i dowody audialne, czyli zawierające informacje postrzegane za pomocą słuchu (płyty, taśmy dźwiękowe). Szeroko wskazuje się również, że wydruki komputerowe mogą stanowić dowód w postępowaniu cywilnym, są bowiem innym środkiem dowodowym, o którym mowa w art. 308 k.p.c. Jakkolwiek nie można przyjąć, że oświadczenie zawarte na wydruku komputerowym jest zgodne z rzeczywistym stanem rzeczy, to należy przyjąć, że przedmiotowy środek dowodowy świadczy o istnieniu zapisu komputerowego określonej treści w chwili dokonywania wydruku. Okoliczność, że tego rodzaju dowody mogą być z łatwością modyfikowane, nie pozbawia ich mocy dowodowej ${ }^{58}$.

Niemniej jednak o dopuszczeniu takich środków dowodowych decyduje sąd, w każdej odrębnej sprawie. Przy czym w postępowaniu cywilnym niedopuszczalne jest prowadzenie dowodu z nagrań uzyskanych w sposób przestępczy, z naruszeniem art. 267 k.k. Nie jest natomiast wyłączone wykorzystanie dowodu z niebędącego wynikiem przestępstwa nagrania utrwalającego rozmowę, w której uczestniczy nagrywający. Dowód z nagrania bez zgody jednego z uczestników rozmowy mogą dyskwalifikować okoliczności, w jakich nastąpiło nagranie, jeżeli wskazują one jednoznacznie na poważne naruszenie zasad współżycia społecznego, na przykład przez naganne wykorzystanie trudnego położenia, stanu psychicznego

57 Wyrok SA w Katowicach z dnia 20 października 2006 roku, sygn. akt III APa 39/06, LEX nr 310425 .

58 Wyrok SA w Warszawie z dnia 13 stycznia 2017 roku, sygn. akt I ACa 2111/15, LEX nr 2249964. 
lub psychofizycznego osoby, z którą rozmowa była prowadzona. Wyrażenie przez osoby nagrane zgody na wykorzystanie nagrania w celach dowodowych przed sądem cywilnym usuwa zazwyczaj przeszkodę, jaką stanowi nielegalne pozyskanie nagrania ${ }^{59}$. Podkreśla się zatem, że sąd przy dopuszczaniu takich środków dowodowych musi zachować szczególną ostrożność z uwagi na to, że nagrania zawierające wypowiedzi mogą zostać wyrwane z kontekstu. Nie bez znaczenia pozostaje również kontekst sytuacyjny ${ }^{60}$.

\section{Wnioski}

Postępowanie dowodowe w sprawach mobbingowych i dyskryminacyjnych zawisłych przed sądami pracy ma szczególne znaczenie i stanowi jeden z najważniejszych elementów postępowania przed sądem. Niemniej jednak jest postępowaniem skomplikowanym między innymi z uwagi na to, że w sprawach mobbingowych postępowanie to jest dwuetapowe - pierwszy etap dotyczy ustalenia, czy mobbing w ogóle miał miejsce, drugi zaś skupia się na badaniu rozstroju zdrowia pracownika, powstałego w związku ze stwierdzonym mobbingiem. Kolejno należy zauważyć, że postępowania sądowe w naprowadzonych sprawach są czasochłonne $\mathrm{z}$ uwagi na wielość faktów występujących w procesach sądowych z zakresu mobbingu i dyskryminacji. Nie bez znaczenia pozostaje również to, że zarówno strony postępowania, jak i świadkowie pozostają w relacjach prawnych i faktycznych ${ }^{61}$. Przy czym sam fakt pozostawania przez świadków w relacjach ze stroną postępowania, nie przesądza o pozbawieniu tych zeznań przymiotu wiarygodności. W każdej konkretnej sprawie sąd orzekający, w granicach swobodnej oceny dowodów, miarkuje czy fakt pozostawania świadka ze stroną w określonych relacjach wpływa na jego zeznania, a jeżeli tak, to jak. Przy ocenie dowodów z zeznań świadków mogących z różnych przyczyn być zainteresowanymi określonym rozstrzygnięciem w sprawie, szczególnie ważne dla tej oceny pozostaje powiązanie tego dowodu z pozostałym materiałem dowodowym ${ }^{62}$.

Podkreślenia wymaga również, że dochodzenie roszczeń na drodze sądowej wiąże się z koniecznością ponoszenia kosztów, a kwoty przyznawane między innymi z tytułu zadośćuczynienia w wysokości kilku czy też kilkunastu tysięcy złotych zdecydowanie nie rekompensują poniesionych wydatków. Należy również zauważyć, że zasądzenie określonej kwoty od pracodawcy nie doprowadzi do zmiany relacji pracownika i pracodawcy. Brakuje podstaw do uznania, że wyrok sądu

59 Wyrok SA w Krakowie z dnia 18 maja 2018 roku, sygn. akt I ACa 1431/17, LEX nr 2589503.

60 G. Jędrejek, Dochodzenie roszczeń związanych z mobbingiem..., s. 281.

61 Ibidem, s. 255.

62 Wyrok SA w Szczecinie z dnia 1 lutego 2017 roku, sygn. akt I ACa 448/16, LEX nr 2306287. 
wpłynie na prawidłowe relacje w miejscu pracy. Ustawodawca nie może z kolei wymusić przy tym właściwej atmosfery w pracy ${ }^{63}$.

Wydaje się, że po zakończeniu sporu sądowego dalsza praca u pracodawcy, z którym toczyło się proces, może nie mieć racji bytu. Pracodawca może czekać na potknięcia pracownika, które w przyszłości przyczynią się do rozwiązania stosunku pracy. Nie ulega również wątpliwości, że analizując orzecznictwo sądów powszechnych z zakresu spraw pracowniczych, większa ich część kończy się przegraną pracownika ${ }^{64}$.

\section{Bibliografia}

\section{Literatura}

Baran K.W., Procesowe prawo pracy, Warszawa 2013.

Błaszczak Ł., Dowody i postepowanie dowodowe w sprawach cywilnych, red. Ł. Błaszczak, K. Markiewicz, Warszawa 2005.

Demendecki T., Kodeks postępowania cywilnego. Komentarz, red. A. Jakubecki, LEX/el., 2018.

Demendecki T., Kodeks postępowania cywilnego, t. 1. Komentarz do art. 1-729. red. A. Jakubecki, Warszawa 2017.

Flaga-Gieruszyńska K., Postępowanie dowodowe w sprawach z zakresu prawa pracy, [w:] System Prawa Pracy, red. K.W. Baran, t. 6. Procesowe prawo pracy, Warszawa 2016.

Jaślikowski M., Prawo sądu do przeprowadzenia z urzędu dowodów niewskazanych przez strony w świetle zasad i funkcji postępowania cywilnego, „Przegląd Sądowy” 2005, nr 11-12.

Jędrejek G., Dochodzenie roszczeń związanych z mobbingiem, dyskryminacją i molestowaniem, Warszawa 2017.

Jędrejek G., Postępowanie dowodowe w sprawie mobbingowej, „Monitor Prawa Pracy” 2008, nr 12. Maniewska E., Kodeks Pracy. Komentarz, LEX/el., 2018.

Manowska M., Postępowanie odrębne w procesie cywilnym, Warszawa 2003.

Naumann E., Dyskryminacja w prawie pracy, „Monitor Prawa Pracy” 2007, nr 6.

Szewczyk H., Równość ptci w zatrudnieniu, Warszawa 2017.

Wróblewski J., Sadowe stosowanie prawa, Warszawa 1988.

Zieliński A., Kodeks postępowania cywilnego. Komentarz, Warszawa 2017.

\section{Akty prawne}

Ustawa z dnia 23 kwietnia 1964 roku Kodeks cywilny (tekst jedn. Dz.U. z 2018 r. poz.1025).

Ustawa z dnia 17 listopada 1964 roku Kodeks postępowania cywilnego (tekst jedn. Dz.U. z 2018 r. poz. 1360).

Ustawa z dnia 26 czerwca 1974 roku Kodeks pracy (tekst jedn. Dz.U. z 2018 r. poz. 917).

63 Ibidem, s. 60.

64 G. Jędrejek, Dochodzenie roszczeń związanych z mobbingiem..., s. $60 \mathrm{n}$. 


\section{Orzecznictwo}

Postanowienie SN z dnia 7 grudnia 2000 roku, sygn. akt II CKN 1322/00, LEX nr 51967.

Postanowienie SN z dnia 24 maja 2005 roku, sygn. akt II PK 33/05, LEX nr 184961.

Uchwała SN z dnia 7 stycznia 2010 roku, sygn. akt II PZP 13/09, LEX nr 537073.

Wyrok SA w Gdańsku z dnia 16 czerwca 2016 roku, sygn. akt III APa 13/16, LEX nr 2356487.

Wyrok SA w Katowicach z dnia 20 października 2006 roku, sygn. akt III APa 39/06, LEX nr 310425.

Wyrok SA w Krakowie z dnia 18 maja 2018 roku, sygn. akt I ACa 1431/17, LEX nr 2589503.

Wyrok SA w Krakowie z dnia 29 sierpnia 2018 roku, sygn. akt I ACa 1635/17, LEX nr 2554202.

Wyrok SA w Poznaniu z dnia 22 września 2005 roku, sygn. akt III APa 60/05, LEX nr 215691.

Wyrok SA w Szczecinie z dnia 1 lutego 2017 roku, sygn. akt I ACa 448/16, LEX nr 2306287.

Wyrok SA w Warszawie z dnia 13 stycznia 2017 roku, sygn. akt I ACa 2111/15, LEX nr 2249964.

Wyrok SN z dnia 7 grudnia 1994 roku, sygn. akt II URN 43/94, LEX nr 121.

Wyrok SN z dnia 5 lutego 1997 roku, sygn. akt I CKU 81/96, LEX nr 50574.

Wyrok SN z dnia 10 grudnia 1997 roku, sygn. akt II UKN 394/97, LEX nr 33911.

Wyrok SN z dnia 7 października 1998 roku, sygn. akt II UKN 246/98, LEX nr 37701.

Wyrok SN z dnia 10 listopada 1999 roku, sygn. akt I PKN 361/99, LEX 40658.

Wyrok SN z dnia 30 listopada 1999 roku, sygn. akt II UKN 220/99, LEX nr 46321.

Wyrok SN z dnia 4 lipca 2000 roku, sygn. akt II UKN 627/99, OSNP 2002/2/50.

Wyrok SN z dnia 12 grudnia 2000 roku, sygn. akt V CKN 175/00, LEX nr 47717.

Wyrok SN z dnia 5 grudnia 2006 roku, sygn. akt II PK 112/06, LEX nr 290991.

Wyrok SN z dnia 29 marca 2007 roku, sygn. akt II PK 228/06, LEX nr 389285.

Wyrok SN z dnia 5 października 2007 roku, sygn. akt II PK 31/07, LEX nr 465076.

Wyrok SN z dnia 24 września 2009 roku, sygn. akt II PK 78/09, LEX nr 558307.

Wyrok SN z dnia 18 kwietnia 2012 roku, sygn. akt II PK 196/11, LEX nr 1297762.

Wyrok SN z dnia 20 lipca 2017 roku, sygn. akt I PK 216/16, LEX nr 2389574.

Wyrok SN z dnia 29 stycznia 2019 roku, sygn. akt III PK 6/18, LEX nr 2619173. 